\title{
Correction to: Determination of serum free light chains as a marker of systemic lupus flare
}

\author{
Ana Belén Rodríguez-Cambrón ${ }^{1}$ • Juana Jiménez-Jiménez ${ }^{2} \cdot$ María Ángeles Blázquez-Cañamero $^{3}$. \\ Francis Rey Pazos ${ }^{1}$. Cristina Macía-Villa ${ }^{1}$ María Alcalde-Villar ${ }^{1} \cdot$ Paz Collado-Ramos ${ }^{1}$. \\ Félix Manuel Cabero Del Pozo ${ }^{1}$. Eva Álvarez-Andrés ${ }^{1} \cdot$ Ana Cruz-Valenciano $^{1}$
}

Published online: 7 March 2022

(c) International League of Associations for Rheumatology (ILAR) 2022

Correction to: Clinical Rheumatology (2019) 39:449-454
https://doi.org/10.1007/s10067-019-04827-4

In the original version of this article, the following author names should have been presented as shown below:

Ana Belén Rodríguez-Cambrón

Juana Jiménez-Jiménez

María Ángeles Blázquez-Cañamero

Francis Rey Pazos

Cristina Macía-Villa

María Alcalde-Villar

Paz Collado-Ramos

Félix Manuel Cabero Del Pozo

Eva Álvarez-Andrés

Ana Cruz-Valenciano

And the citations should have been:

Rodríguez-Cambrón, AB

Jiménez-Jiménez, J

Blázquez-Cañamero, MA
Pazos, FR

Macía-Villa, C

Alcalde-Villar, M

Collado-Ramos, $\mathrm{P}$

Manuel Cabero Del Pozo, FM

Álvarez-Andrés, E

Cruz-Valenciano, A

The original article has been corrected.

Publisher's note Springer Nature remains neutral with regard to jurisdictional claims in published maps and institutional affiliations.

The original article can be found online athttps://doi.org/10.1007/ s10067-019-04827-4.

Ana Belén Rodríguez-Cambrón

anabelen_r_c@hotmail.com

1 Division of Rheumatology, Hospital Universitario Severo Ochoa, Avda. de Orellana s/n CP 28911, Leganés, Madrid, Spain

2 Division of Biochemistry, Hospital Universitario Severo Ochoa, Madrid, Spain

3 Division of Rheumatology, Hospital Universitario Ramón y Cajal, Madrid, Spain 